\title{
Islamic Architecture in Iran, A Case Study on Evolutionary of Minarets of Isfahan
}

\author{
Katayoun Taghizadeh
}

Department of Architecture, University of Tehran, Tehran, 1417466191, Iran

\begin{abstract}
In ancient time, a minaret was built between two borders and something bright was put into it to show the respective frontier, and gradually such minarets were also built in traveler's route to enable the passengers and caravans to recognize their route and destination.After the rise of Islam, and in Islamic countries such minarets were built for calling to prayer and therefore, in most places where such minarets were constructed after Islam, they were linked to mosques or buildings which were considered to be religious and sacred. One of the practical aspects of tin minarets connected to verandas and domes in mosques was the quality of creating resistance and prevention of the dome or the veranda from falling down. The minarets in Iran after converting to Islam have become parts and parcels of the mosques, and nowadays, and in spite of the advances made in construction technology, due to their sacred and spiritual nature, minarets still continue to be built in the mosques.In this article Based on the field investigation has been done 2006-2010 and through introducing various kinds of minarets in Iran from the aspects of structure and form, the best types of minarets which has been built in different centuries in the city of Isfahan will be studied and analyzed, from different aspects of form, shape, structure and ornaments.
\end{abstract}

Keywords Minaret, Islamic Architecture, Mosque, Iran, Structure

\section{Introduction}

There is no doubt that the unforgettable message in the Iranian architecture has been the preservation of the multiple aspects of the buildings constructed by the Iranian architects and artists, all through ages and specially during the Islamic period. Among others, mention can be made of the tall minarets of the Iranian mosques, that, while being places for calling to prayers and proper places for inviting the believers towards their god, they are a symbol of prosperity and inseparable part beside the mosques, and while preserving their efficiency and having the ability of possessing a single value, they own their specific features as an independent work of art. One of the practical aspects of twin minarets connected to verandas and domes in mosques was the quality of creating resistance and prevention of the dome or the veranda from falling down.[1]

\section{Objectives}

In Iranian traditional architecture, elements like light play an outstanding role in the religious art and specially the Islamic architecture and the Iranian mosques and minarets

* Corresponding author:

ktaghizad@ut.ac.ir (Katayoun Taghizadeh)

Published online at http://journal.sapub.org/arch

Copyright $(C) 2012$ Scientific \& Academic Publishing. All Rights Reserved which have adopted their names from the word "light". In all construction, the presence of light, and having access to it, was a basic requisite.

This survey was carried out on a considerable historical buildings indicates that minarets can be deemed as places for taste and elegance, places for manifestation of colors and various types of art and an exhibition of the works of Moslem architects and artists with a view to the realization of their beliefs and religious convictions.

\section{History}

The nature of a minaret, unlike other Islamic buildings like schools and caravanserai, can immediately and without any hesitation, be recognized.

Generally speaking, it seems that there is not any connection between a minaret and its being utilized as a means for calling to prayers, so that in the beginning stage of Islam, this was done quite naturally, and later on with the increase in population and involvement of people in business and routine life, it was decided that calling people to prayer be done in a loud voice when they intend to say prayers.[1]

\section{Etymology}

The terms used to name this kind of architecture are chosen according to the application of this construction, and in this paper are referred to Minaret, Monastery and Me' Zane which are used interchangeably. 
Among these three terms, MINARET or MINAR is much more commonly used than others, although the term itself has three variant pronunciations, MANARET, MONAREH and MENAREH but its original meaning is a place of light and fire considering its Turkish root, it means to be a proper root for the English word Minaret.[1]

In the pre-Islamic Arabia, this term was used to mean a high place where signals were sent out by using fume or light. That is why a minaret was generally assumed to be a lighthouse.

The second term which is normally used to mean minaret and in fact it has a standard application in the North Africa is the term "monastery". The term means a cell in which the Christians live in seclusion (a cell has a thin and sharp head).

They were linked together in these cells and in large rectangular towers, which the churches and abbeys where equipped with them. The root of this term, like minaret, is misleading, since the original meaning of monastery is in fact seclusion.

This term, in the process of the part and whole is used to mean a complete building which the cell constituted a small part of it.

Interestingly enough, the two Arabic words which are often used for a minaret, give no clue to the religious ceremonies and rites, with which the building has been deeply intermixed for centuries. Instead, they have signs of Christian and pre-Islamic associations respectively.

The term that satisfactorily explains the religious ceremonies of the building is MEZANE which is derived from the word IZAN, and means a place where people are invited.

An etymological study of minaret, will lead us to the idea that in different times and places, and depending on the applications of the building, specific names were chosen for a minaret.

At the same time, it is mentionable that etymology cannot be a reliable guide in identifying a minaret's performance.

In view of the above points, the Iranians who had recently converted to Islam came to the idea of using minarets and with justification that a minaret is a place of light, they built mosques beside them. The minarets located outside the cities were used both as road guides and mosques and later on they lead the tired passengers to the Caravansaries. And the city minarets too, were used in order to glorify the space for inviting people to religious duties and specially prayer.

A minaret's structure

Minarets are comprised of four basic parts:

- Base: in the shape of a square a hexagon or a dodecagon.

- Stem: in the shape of a cylinder or a cone.

- Cap: in the shape of a square or an octagon and in fact the most important part of the minaret.

- Head: it is an awning which is built in different shapes.

\section{The Historical Root of the Iranian Minarets}

In any discussion which is generally rise among re- searches about the principles and the structural roots of the Iranian minarets.

We can mention the temples and ziggurats of the Mesopotamia, stone masses or pillars which were erected by ancient tribes of the central Asia in commemoration of their triumphs the towers, obelisks and ancient fire temples of Achalmenian and sassanid periods and before that, and even Greek style pillars. Among the oldest memorial towers, braziers, impressive as the minarets and were used for objectives more or less the same as ones pertaining to the Islamic period in Iran and other countries, we refer to the falling list:

1. The Noorabad tower, commonly known as Draggon's obelisk belmging to the Parthian Era (224 A.D.-250 B.C.) in Fars province.

2. The Firoozabad fire tower, the sassanid Era (224 A.D. 651), far

3. The Babylonian tower, in the time if Hamourabi (2003-1961 B.C.), which was built for Mardiuk the God of Babylonia.

4. Choghazambil ziggurat to Ontashgal (1234-27 B.C.), Susa.

5. zoroaster's kabaa, which is square-based tower, opposite the stone tomb of Dariush. Rostam's picture, in Fars province.

6. The Alexandrian Lighthouse.

7. Minaret of St John, church, in Damascus.

8. The Ghabous Dome (1006-7 A.D.) [1]

\section{Classification of the Iranian Minarets as Regards Their Forms}

From the view point of the Islamic culture researchers it seems that the idea of erection of minaret, first appeared in Syria and in the time of the Umayyad Caliphate. But in Syria, Egypt and Morocco, the Cylindrical minaret which gradually become thinner from down to upward, become fashionable and as a rule, the Iranian minarets can be divided into three major types from the aspect of their apparent forms and structures.[2]

1. The Cylindrical minarets: which they often have plain figures and in few cases, very simple ornaments are seen in their Cylindrical bodies. For instance, we can refer to the minaret of Khorramabad, Golpayegan, and minaret of the Friday mosque in Tafresh city and minaret of sheikh Danial in Khonje, in Larestan city.

2. The conical minarets: such minarets are often slender and are like oblige and well- shaped cons. This kind of body can result in the more strength and resistance of the minaret and as examples we refer to minarets of Damghan, Semnan, Bastam, Sareban, and Ali minaret in Seaman. Such conical minarets have passed their height of prosperity in the 5th and 6th centuries after the Hegira, which are among the notable centuries in the Iranian architecture. For instance, some of those minarets had two or three stories, and the thinner and 
shorter stories were located on the others, and in some cases every story had its own Me' Zane and crown, such as Tabriz and Golpayegon Friday mosques.

3. The prismatic minarets: Such minarets, which only a few numbers of them exist in Iran, seem to be polygonal at the base, and the more they go up, their base diameters are reduced. The Naein Friday mosque minaret and the short minaret of the Imam Hassan Asgary mosque in Amol can be mentioned as example.

\section{A Study of Historical Examples of Minaret in Isfahan}

For a number of reasons, Isfahan is called the city of minarets:

1. Isfahan had been the capital city in different eras.

2. Isfahan being located in an area which has the least earth quakes.

3. Most of the roads being lead to Isfahan.

4. Isfahan's towers for the study of the signs of the zodiac.

If the minarets be divided into various historical eras, the Isfahen minarets can be directed into three historical eras.[3]

1. The early minarets (5-6 centuries) such as Ali, Sareban and Chehel Dokhtar (Forty Girls) minarets. No such things as ornaments and tile setting can be seen in this period.

2. Before the Saffavid (civilization of the Mozaffar and Bouyeh Families) such as the main minaret of the Friday mosque, and the Dardasht minaret. Brick and tile setting involved in this period.

3. After the Saffavids: the mosque of Shah the Charbagh mosque which are totally ornamented.

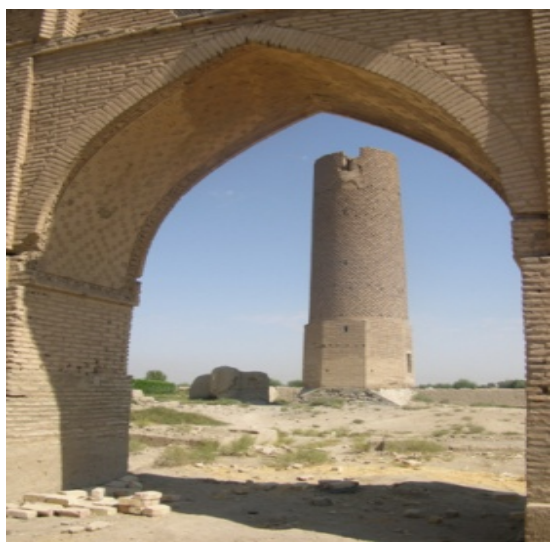

Figure 1. The Gar Minaret Elevation

\subsection{The Gar Minaret}

The Gar village which is pronounced "jar" by its residents is located at a distance of 22 kilometers east of Isfahan are on the bank of the Zayandeh-Rud River. The minaret has a distinct background and its upper part is collapsed and is established on an octagonal base. The hidden base of the minaret is slightly narrower upward than downward and has a height of 4.8 meters upward.[7]

The height of the minaret with its base (which is in the shape of an elephant's leg) is currently 21 meters. In the upper part of the minaret there is a big window facing Mecca and it has a small veranda. There is no tile in this minaret and the mortar used is plaster and soil.

Except for a part of its foundation which has protruded, the rest of the building is in good condition. The minaret's inscription which is in its lower part and in the upper section of its octagonal base is carved in Kufic script on raised variegated title and is written in one line and dates back to the year 515 of the Hegira.

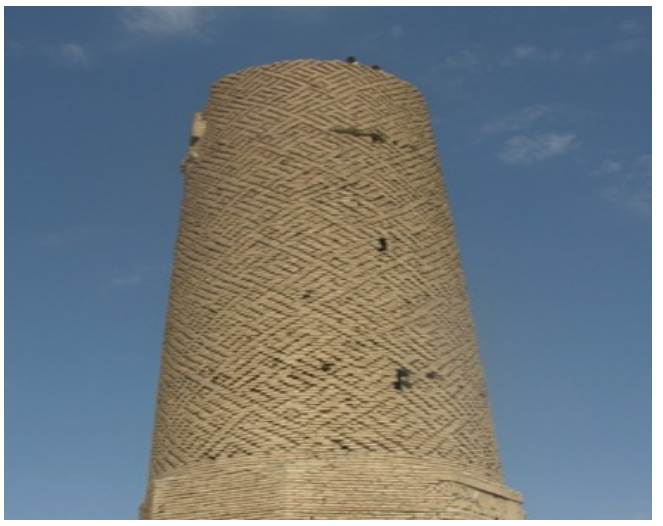

Figure 2. The Gar Minaret View

\subsection{The Barsian Minaret}

Among the oldest buildings that exist in Isfahan and have specific dates, we can mention the Barsian minaret. This minaret that is unique and circular and its tiles are stuck with a mortar of plaster, has a diameter of $5.75 \mathrm{~m}$ at the surface and $4.2 \mathrm{~m}$ in the upper section and a height of about $35 \mathrm{~m}$. It's unique and spiral staircase stars from the earth surface and people can enter it through a mosque which was built later on. This staircase turns counter-clockwise round a circular column with diameter of $82 \mathrm{~cm}$ at the bottom and $72 \mathrm{~cm}$ at the top. The illumination inside the minaret is obtained through narrow and vertical apertures around it. At the middle of the minaret's stem there is a big window facing Mecca. The body of the minaret, due to its sagging, is a little bent above the window. The lower part of the minaret is bricked in simple fashion and the upper of it are bricked ornamentally. In the upper part or the ring of the minaret, two margins with a slight protrusion, which practically make its crown, are seen.

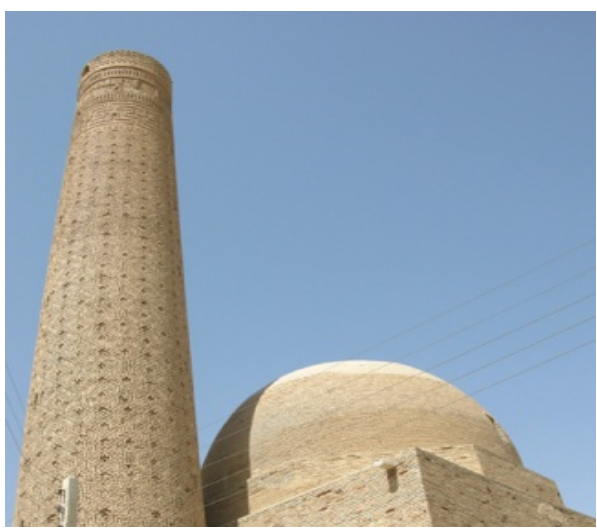

Figure 3. The Barsian Minaret adjacent dome of mosque 
No tile is used in the ornaments of the minarets. Inside the margins of the main body of the minaret in the upper section, figures of rhombus and circle have been used alternately. Such patterns have been customary in the brickworks in the Seljuk period in Isfahan and continued to exist until the Mongol time. The ornaments in the crown of the minaret differ from those in its body. In this section the minaret's inscription is in simple Kufic script and brick-colored.[5]

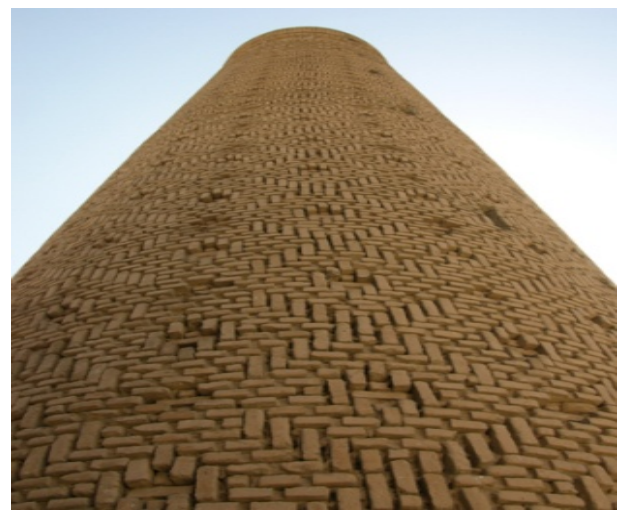

Figure 4. The Barsian Minaret brick work

The inscription indicates that the date of minaret construction is 491 after the hegira. This minaret is an example of the Seljuk buildings in the fifth century after the Hegira and embraces all the best technical points in brickwork.

\subsection{The Forty Girls Minaret}

The Forty Girls minaret is located in the further most north of the Joobareh quarter which is one the old quarters of Isfahan and a Jewish ghetto. This round minaret has a height of 24 meters and if we take into account the five meters height of the brick platform of the minaret's base, the total height becomes 29 meters. The minaret's diameter id 2.9 meters at the base and gets narrower at the top. The platform that the minaret rod is erected on, it is in the shape of an octagon.

The minaret's body is decorated with various designs and in the uppermost part the minaret the crown is seen with a slight prominence.

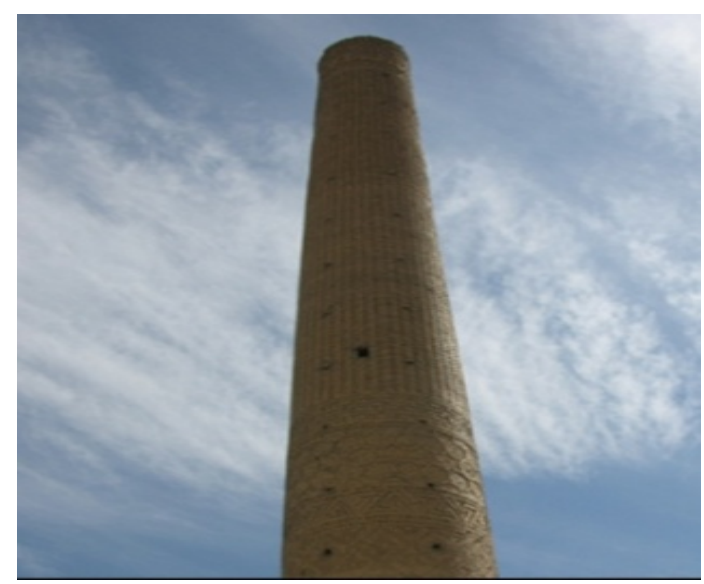

Figure 5. The Forty Girls Minaret brick work

In the upper section of the minaret and in the second third-part of it, and southward, there is a big window that has a rectangular opening which the upper part of it is made of wood and in its two sides there are round and small columns that half part of them are inserted into the minaret wall. The upper inscription of the minaret is in the Kufic script on raised bricks and on its brick background the first 5 verses of the Taha chapter of the holy Quran is written and in the upper part of the base or the platform of the minaret in THOLTH script and on raised bricks a beautiful inscription is carved in plaster.

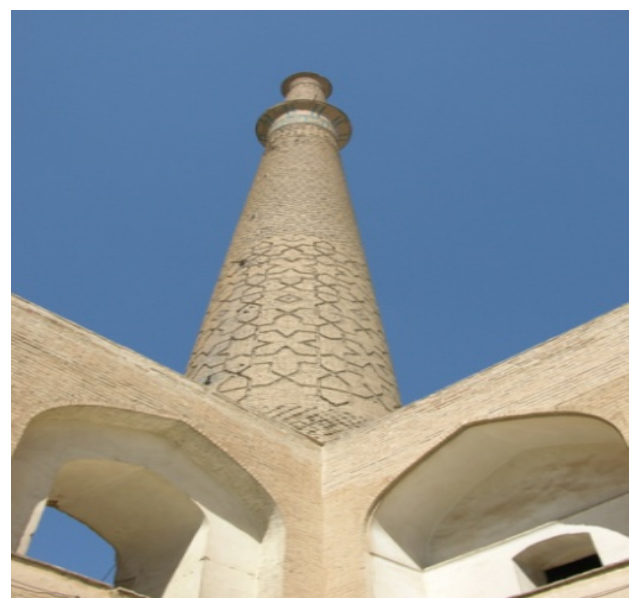

Figure 6. The Forty Girls Minaret elevation

\subsection{The Ali Minaret}

This is one of the most famous minarets of Isfahan. The Ali minaret stands on the north-west of the Ali mosque (from the monuments of the period of Shah Ismail the 1st in the area of a Seljuk mosque) and its etymological roof is its proximity to the Ali mosque.

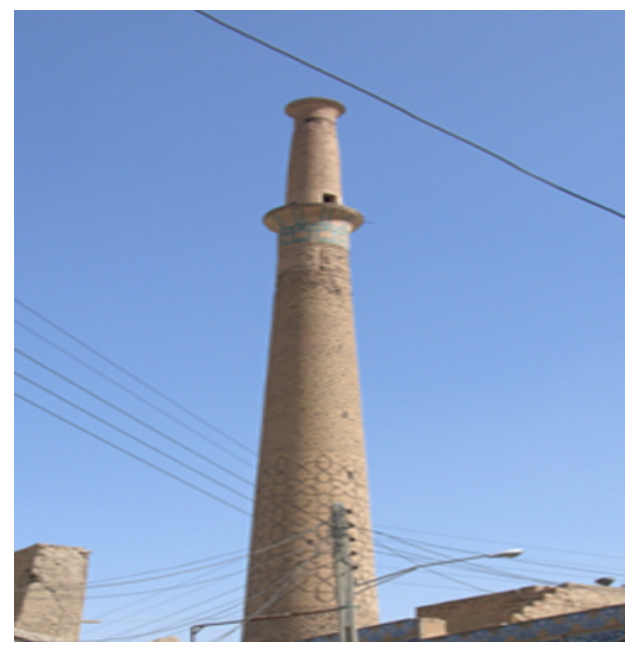

Figure 7. The Ali Minaret elevation

The main body of the minaret is made of bricks, and round rod is divided into three parts and part is thinner than the other, or it might be said that the minaret is composed of three rods. Each of the two lower rods is decorated with a saucer-like crown. The current height of the minaret up to the first crown is 40.35 meters, the middle part 7 meters and what is remained from the upper part is half a meter. And therefore, its height is on the whole 47.75 meters. It is be- 
lieved that its original height had been more than 50 meters. The diameter of the minaret's body is 6 meters in the lower part. And is reduced to 2 meters in the upper part.[6]

Ornaments in the lower part of the minaret stem includes polygons, crosses, sixth and eight-pronged stars and elegant rhombuses.

The middle part of the stem consist of jagged rhombuses that form diagonal left and right intersecting strips and inside each rhombus another small jagged rhombus id devised. These rhombuses, as compared to the minaret's stem, that gets narrower due to its conical shape, have less area. There are two inscriptions carved on the bricks in NASKH script and create a special diversity among the geometrical designs below and the crown above them. The saucer-like crown that forms $93 \mathrm{~cm}$ of the minaret's body, through laying bricks vertically and diagonally, suggests a figure with radical lines that resembles a carnation. In the upper part of the crown, there are designs like those in the middle of the slim. The inscription beside the second crown, which has been formed through laying pieces of tile in mosaic style and in NASKH script, with its turquoise color, has a special beauty and impression near the earth colored bricks. The second crown and its upper rod are ruined now and have probably had ornaments like those of it lower crown and rod. From upwards down, the minaret has 5 inscriptions that many of its letters have dropped. The first inscription is in Kufic script and in turquoise colored tiles one brick background, which is a repetition of the verse, "there is no god but Allah."[4]

\subsection{The Sareban [Camel Driver] Minaret}

This minaret is one of the most beautiful minarets of Seljuk period in Isfahan.

It is located in the nor then most part of the Joobareh quarter which is the Jewish ghetto of Isfahan and near the Forty Girls minaret and on the corner of a small square in the place, at the time of its construction. The minaret's height is about 48 meters and its base circumference is 14 meters and from down to upwards it has seven distinct parts: The first part is unadorned brickworks. The second and third parts have magnificent brick ornaments. The forth part is the first crown of the minaret which has corniced parts with beautiful turquoise color bricks and tiles. Its fifth is brick ornaments.[5]

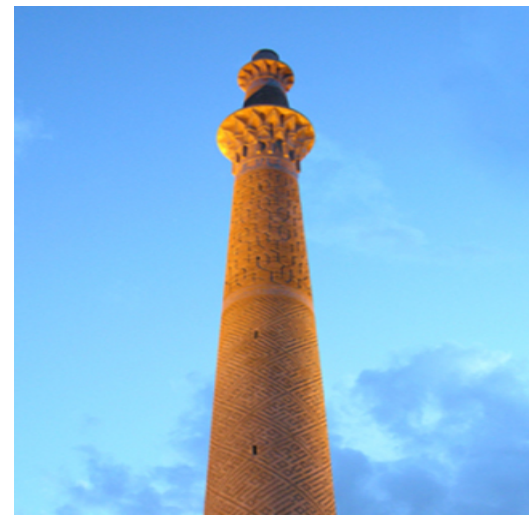

Figure 8. The Sareban Minaret view
The sixth part is the second crown of the minaret and the seventh part is its spire. In the base of the two crowns of the minaret there are two very beautiful inscriptions with best turquoise tile which could be seen and read. The minaret, in which the original height is reduced a little, is currently inclined westwards and the inclination is quite visible from far and near. The year of the minaret construction is not nor seen in the inscriptions can't therefore the construction date be determined definitely. Professor pope believes that the construction year of the building dates back to end of the 5th century after the Hegira.

In the history of Isfahan it is written that the Sareban minaret which resembles the minaret in the Ali mosque, Ha 135-5-leps and the width of each step is $66 \mathrm{~cm}$.

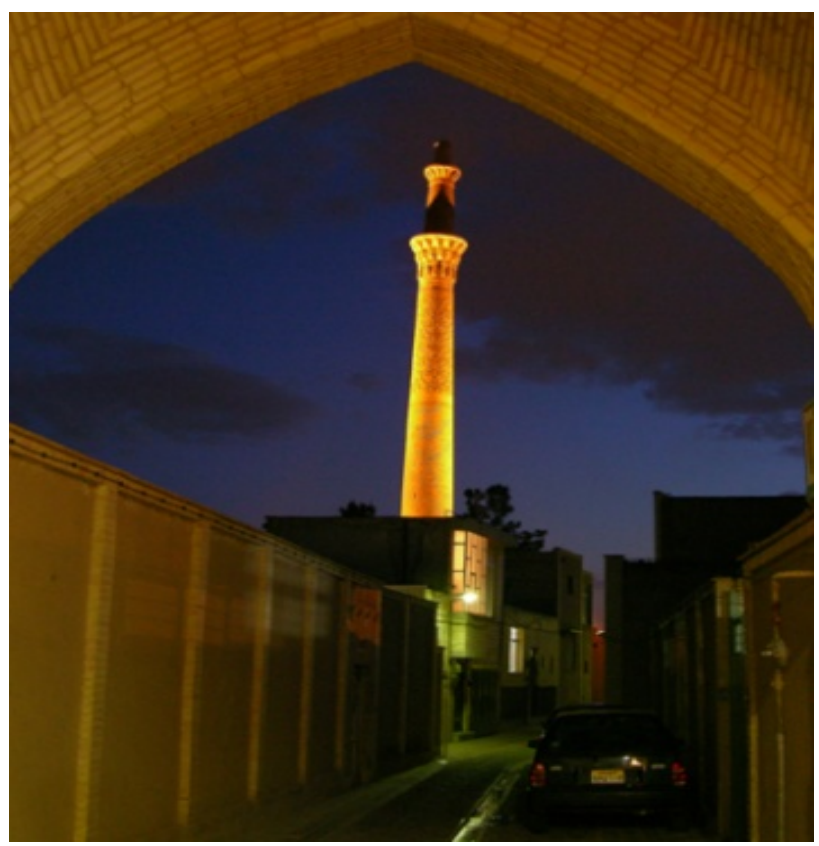

Figure 9. The Sareban Minaret elevation

\section{Results}

Minaret is considered to be the basic elements of the Islamic technique art. All the Islamic mosques and minarets have been constructed for the preservation and expression of one single objective; however, all of them possess their own specific features of form, performance, structure and ornament.

Meanwhile, even the construction of the most colossal buildings and engaging with the finest decoration have not distracted the maker from precision and saving the quality. The taste and elegance of the skilful architect does not show the faintest deficiency against the largeness of the work.

Site investigations illustrated that in the traditional Persian architecture, the shapes and the forms have gone beyond their material and familiar meaning and in every direction they acquire a higher quality than their apparent ones. The geometrical shapes of the square, circle, and octagon and so on, have their own value position and are symbols of the artist's religious beliefs; but beyond the geometrical shape 
and material volumes and sizes, even elements like light have their outstanding position in the religious art. Especially the Islamic architecture and the Iranian mosques and minarets, which have taken their names from "light."

\section{Conclusions}

The studies made on the 5 important minarets in Isfahan (the city of minarets), have clarified the point that the minarets during the Pre-Islamic era and specially after Islam, have passed their evolutionary period as to their structure and decoration and every period is an expression of its technology of building and the method of using the ornaments in the architecture of the period concerned.

Today, and in spite of the advances in the building technology, minarets are still used as a basic element in the design and construction of the mosques.

Modern mosques today, are not in need for minarets for resistance purposes, but because of their sacred and spiritual aspects, they are clearly visible beside the mosques.

\section{REFERENCES}

[1] Pope, A.U. (1987), Persian Architecture, Farhang Sara, Tehran, Iran
[2] Rice, Tamara T. (1961), The Seljuk in Asia Minor, London

[3] www.islamic-art.net

[4] www.isfahan.us

[5] www.isfahan.org.uk

[6] www.360cities.net

[7] www.kufic.info.com

[8] Pourjafar, M., Pourjafar, A. and Shahinrad, M. (2011), Evolution Of Towers And Minaret Of Islamic Architecture From Qabus Tower To Malaysian Petronas Twin Towers (Klcc), International Journal Of Academic Research Vol. 3. No.1. January, Part II

[9] Pirniea, M.K., (2001) . Architectural Styles of Iran. Tehran

[10] Pirniea, M.K., (1988) History of Anc ient Iran. Tehran

[11] Smith, Jonathan; 2010; Intrnet Address: http://janotansmith.p ersianblog.ir/post/2, Access Date 6/April/2010

[12] Abbasi, Zabol; 2009; Internet Address: http://www.civilmast er.ir/fa , Access Date 19/July/2009. 2. Ghezelje, Matin; 2009; Qabus Tower, Internet Address: http://bayragh.ir/ , Access Date 11/July/2009

[13] Majidi, Mohammad Reza; 2009; Qabus Tower, the tallest brick work tower in the world, Internet Address: http:// engmmajidee.blogfa.com, Access Date 3/August /2009

[14] Burckhardt, Titus (2009), Art of Islam, Language and Meaning: Commemorative Edition. World Wisdom 